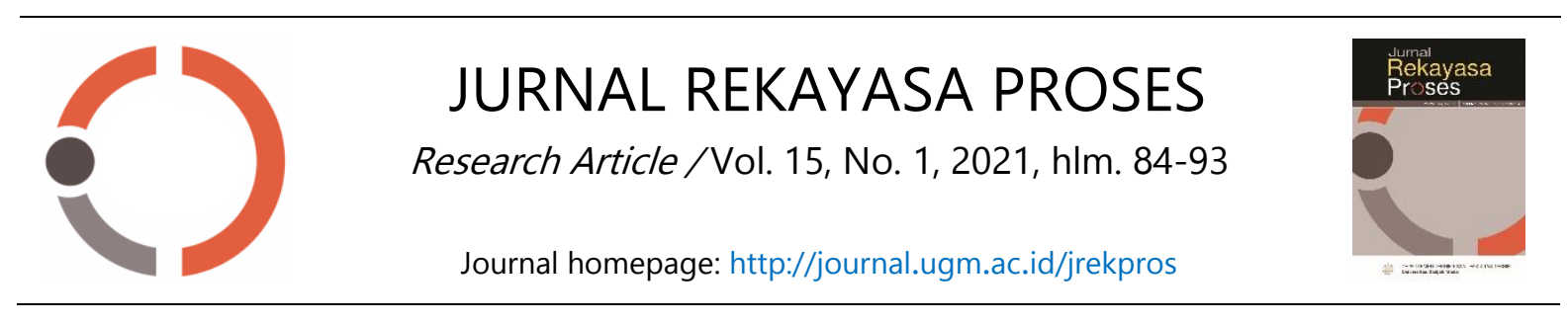

\title{
Preparasi Katalis MgO/C dari Pirolisis Polimer Berbasis Magnesium Salisilat dan Aplikasinya untuk Reaksi Transesterifikasi
}

Imam Prasetyo*, Dwiana Ayu Kiranti Nur'aeni, dan Pandu Timur Bhaskara Departemen Teknik Kimia, Fakultas Teknik, Universitas Gadjah Mada JI Grafika No. 2 Kampus UGM, Yogyakarta, 55283

*Alamat korespondensi: imampras@ugm.ac.id

(Submisi: 14 Mei 2021; Revisi: 31 Mei 2021; Penerimaan: 3 Juni 2021)

\section{ABSTRACT}

The objective of the study is to produce carbon-based magnesium oxide (MgO) solid base catalyst by pyrolysis of phenolic resin and to examine the material effectiveness as a catalyst for transesterification reaction. The phenolic resins were prepared by polymerization process of phenol, derivative salicylic acid (magnesium salicylate), and formaldehyde aqueous solution under acidic condition using $\mathrm{H}_{2} \mathrm{SO}_{4}$ as catalyst. The molar ratio of magnesium salicylate:phenol:formaldehyde was 0.33:0.67:2.80. Carbon-based magnesium oxide solid base catalyst $(\mathrm{MgO} / \mathrm{C})$ was produced from phenolic resins via physical activation process using steam at $850^{\circ} \mathrm{C}$. Material was characterized using $N_{2}$-sorption analysis, $X$-ray diffraction (XRD) and scanning electron microscopy (SEM). Pyrolysis process for carbon formation resulted in $75 \%$ burn-off. The specific surface area of catalyst was $494 \mathrm{~m}^{2} / \mathrm{g}$ and the presence of $\mathrm{MgO}$ was confirmed by XRD diffraction pattern (20 position of $36-43^{\circ}, 61-63^{\circ}$, dan $74-78^{\circ}$ according to JCPDS No.89-7746) and SEM image. Characteristic comparison of $\mathrm{MgO} / \mathrm{C}$ with carbon produced from phenol formaldehyde resin (without magnesium salicylate) corroborate the finding that $\mathrm{MgO} / \mathrm{C}$ was achieved. The catalyst was tested for transesterification reaction between palm oil and methanol. Conversion of $28.3 \%$ was achieved at temperature of $65{ }^{\circ} \mathrm{C}$, reactant ratio of methanol: palm oil $=6: 1$ and reaction time of 2.5 hours. The activation energy of $6,444 \mathrm{cal} / \mathrm{mo} /$ was obtained when evaluated in the range of $55-65^{\circ} \mathrm{C}$ reaction temperature.

Keywords: biodiesel; catalyst; magnesium oxide; phenolic resin; porous carbon

\section{A B S T R A K}

Tujuan penelitian ini adalah membuat katalis magnesium oksida $(\mathrm{MgO})$ yang teremban dalam karbon hasil dari proses pirolisis resin fenolik dan menguji efektivitasnya sebagai katalis reaksi transesterifikasi. Resin fenolik diperoleh melalui proses polimerisasi fenol, turunan asam salisilat (magnesium salisilat), dan formaldehid dalam kondisi asam menggunakan $\mathrm{H}_{2} \mathrm{SO}_{4}$ sebagai katalis. Rasio mol dari magnesium salisilat:fenol:formaldehid adalah 0,33:0,67:2,80. 
Katalis magnesium oksida teremban pada karbon $(\mathrm{MgO} / \mathrm{C})$ diperoleh dari pirolisis resin fenolik menggunakan steam pada suhu $850^{\circ} \mathrm{C}$. Material dikarakterisasi dengan $\mathrm{N}_{2}$ adsorpsi-desorpsi isotherm, X-ray diffraction (XRD) dan scanning electron microscopy (SEM). Pirolisis untuk menghasilkan karbon memiliki burn-off sekitar $75 \%$. Hasil penelitian menunjukkan bahwa katalis $\mathrm{MgO} / \mathrm{C}$ memiliki luas permukaan sekitar $494 \mathrm{~m}^{2} / \mathrm{g}$ dan keberadaan MgO dikonfirmasi dari hasil pola difraksi XRD (posisi $2 \theta$ antara $36-43^{\circ}, 61-63^{\circ}$, dan $74-78^{\circ}$ sesuai dengan standar JCPDS No.89-7746) dan gambar SEM. Pembandingan karakteristik MgO/C dengan karbon hasil polimer fenol formaldehid (tanpa magnesium salisilat) memperkuat kesimpulan bahwa MgO/C dapat diperoleh. Katalis yang diperoleh digunakan sebagai katalis transesterifikasi antara minyak kelapa sawit dengan metanol. Konversi reaksi sebesar $28,3 \%$ didapatkan pada suhu $65{ }^{\circ} \mathrm{C}$ dan rasio reaktan metanol:minyak kelapa sawit $=6: 1$ dan waktu reaksi 2,5 jam. Energi aktivasi sebesar $6.444 \mathrm{kal} / \mathrm{mol}$ diperoleh pada rentang suhu reaksi $55-65^{\circ} \mathrm{C}$.

Kata kunci: biodiesel; karbon berpori; katalis; magnesium oksida; resin fenolik

\section{Pendahuluan}

Transesterifikasi minyak nabati dengan metanol merupakan proses yang penting untuk menyintesis metil ester dari asam lemak (yang dikenal sebagai biodiesel), yang dapat menggantikan bahan bakar diesel konvensional. Katalis untuk memproduksi biodiesel biasanya berupa katalis homogen basa seperti hidroksida dari logam alkali atau alkali tanah. Kendala utama pada penggunaan katalis homogen adalah pada proses pemisahannya yang secara teknis lebih sukar dan akan menghasilkan air limbah dalam jumlah besar untuk memisahkan dan membersihkan katalis dan produk. Oleh karena itu, orang mulai beralih untuk mengembangkan katalis heterogen dalam proses transesterifikasi minyak nabati untuk membuat biodiesel seperti hidrokalsit, zeolit, dan $\mathrm{Na} / \mathrm{Al}_{2} \mathrm{O}_{3}$.

Magnesium oksida merupakan material yang serbaguna selain digunakan sebagai bahan superkonduktor dan adsorben juga dapat digunakan sebagai katalis. Katalis $\mathrm{MgO}$ dapat digunakan sebagai katalis untuk produksi biodiesel (Natewong et al., 2016), butanol dari etanol (Cimino et al., 2019), degradasi asam oksalat dengan proses ozonasi (Haidari et al., 2016), adsorpsi $\mathrm{CO}_{2}$, dan penghilangan $\mathrm{H}_{2} \mathrm{~S}$ (Siriwardane et al., 2017).

Magnesium dalam bentuk oksidanya memiliki sifat seperti tidak beracun, stabil dalam air, dan ramah lingkungan sehingga mendukung penggunaan $\mathrm{MgO}$ sebagai katalis (Asgari et al., 2019). Selain itu, material logam magnesium memiliki harga ekonomis dan proses pembuatan yang sederhana. Proses sintesis katalis magnesium oksida dapat dilakukan melalui dekomposisi berbagai jenis garam magnesium. Akan tetapi, padatan magnesium oksida yang diperoleh dari metode tersebut memiliki ukuran butir yang besar dengan morfologi yang tidak homogen sehingga metode ini tidak memungkinkan untuk memproduksi magnesium oksida yang akan digunakan sebagai katalis. Metode lain yang dapat menghasilkan magnesium oksida dengan ukuran butiran lebih kecil serta mempunyai luas permukaan yang besar yaitu dengan metode sol-gel hypercritical drying. Pembuatan magnesium oksida dengan metode sol-gel hypercritical drying 
menghasilkan butiran dengan ukuran sekitar $5 \mathrm{~nm}$ (Ding et al., 2001). Namun metode solgel hypercritical drying kurang disukai karena perlu prekursor logam yang berbahaya dan mahal. Alternatif metode yang dapat dilakukan agar diperoleh luas permukaan spesifik katalis $\mathrm{MgO}$ yang lebih besar adalah dengan mengembankan magnesium oksida dalam padatan berpori seperti zeolit, silika, alumina dan karbon. Sebagai pengemban katalis, karbon banyak dipakai karena keunggulannya seperti memiliki luas spesifik permukaan tinggi, inert dalam suasana asam dan basa serta gugus fungsi permukaan yang dapat diatur. Metode konvensional dalam pengembanan katalis $\mathrm{MgO}$ dalam padatan berpori adalah dengan menggunakan metode impregnasi prekursor seperti $\mathrm{Mg}\left(\mathrm{NO}_{3}\right)_{2}$ dalam karbon dan kemudian kalsinasi, sehingga diperoleh $\mathrm{MgO} / \mathrm{C}$ (Haidari et al., 2016; Natewong et al., 2016).

Karbon berpori merupakan material yang memiliki luas permukaan besar karena adanya pori-pori internal dalam karbon. Oleh karena itu, karbon berpori dapat digunakan sebagai adsorben, katalis dan pengemban katalis (Prasetyo et al., 2013, 2018). Aplikasi karbon sebagai katalis telah mengalami peningkatan, baik sebagai pengemban atau sebagai katalis itu sendiri. Sifat spesifik dari material karbon yang merupakan hasil dari kombinasi struktur pori karbon dan struktur kimia permukaannya menghasilkan karbon yang memenuhi syarat terjadinya reaksi katalitik tertentu. Gugus fungsi yang terdapat di permukaan karbon dapat berfungsi sebagai sisi yang menahan katalis logam yang diembankan atau menjadi sisi aktif untuk reaksi katalitik yang spesifik (Glasel et al., 2015).

Pada penelitian ini katalis $\mathrm{MgO}$ akan diembankan pada material karbon berpori (disebut dengan $\mathrm{MgO} / \mathrm{C}$ ) dengan cara penambahan magnesium salisilat secara langsung saat sintesis polimer prekursor karbon. Prekursor karbon berpori akan dibuat dari polimer tiga bahan sintetis yaitu phenol, magnesium salisilat, dan formaldehyde. Alasan pemilihan bahan sintetis yang digunakan dalam penelitian ini karena kualitas karbon dari bahan sintetis akan lebih seragam dan struktur molekulnya dapat dimanipulasi untuk memperoleh karakteristik tertentu. Proses pembuatan karbon sebagai pengemban katalis $\mathrm{MgO}$ yaitu dengan membuat polimer ketiga bahan tersebut pada berbagai rasio reaktan dalam kondisi asam. Polimer yang diperoleh kemudian dipirolisis untuk memperoleh katalis $\mathrm{MgO}$, kemudian material dikarakterisasi dan diuji untuk reaksi transesterifikasi antara minyak kelapa sawit dan metanol.

\section{Metode Penelitian}

\subsection{Bahan Penelitian}

Bahan yang digunakan dalam penelitian meliputi bahan utama dan bahan pendukung. Bahan baku utama yaitu bahan resin fenolik dan bahan pembuatan material karbon berpori. Bahan resin fenolik yang digunakan di antaranya adalah fenol (Merck), formaldehid 37\% (Merck), magnesium salisilat teknis (Haihang Industry). Asam sulfat dengan kadar 95-97\% (Merck) digunakan sebagai katalis reaksi polimerisasi fenolik resin. Untuk reaksi transesterifikasi, digunakan minyak kelapa sawit dan metanol teknis (95\%).

\subsection{Cara Penelitian}

\subsubsection{Pembuatan Prekursor Katalis $\mathrm{MgO} / \mathrm{C}$}

Pembuatan polimer dilakukan dengan pencampuran bahan dalam labu leher tiga yaitu magnesium salisilat:fenol:formaldehid 
dengan perbandingan bervariasi $0,33: 0,67$ : $2,80$ ( $\mathrm{mol} / \mathrm{mol})$. Pencampuran dilakukan dengan urutan magnesium salisilat dilarutkan dengan formaldehid. Sebelum pengadukan, katalis asam berupa $\mathrm{H}_{2} \mathrm{SO}_{4}$ ditambahkan. Penambahan katalis akan mempercepat laju reaksi sehingga suhu campuran akan naik. Ketiga bahan tersebut dicampur sembari dipanaskan pada $80{ }^{\circ} \mathrm{C}$ hingga diperoleh campuran yang homogen. Selanjutnya, fenol ditambahkan ke dalam campuran. Proses pengadukan terus dilakukan hingga terbentuk padatan lalu campuran didiamkan sampai reaksi kondensasi tuntas dan suhu kembali normal (Haus et al., 1981; Nur'aeni, 2019). Resin yang terbentuk diberi nama MPF.

Sebagai pembanding, dibuat pula polimer fenol formaldehid tanpa penambahan magnesium salisilat. Rasio $\mathrm{mol}$ fenol : formaldehid adalah $1: 2,8$. Pencampuran dilakukan dengan urutan fenol dilarutkan dengan penambahan formaldehid. Sebelum pengadukan katalis asam berupa $\mathrm{H}_{2} \mathrm{SO}_{4}$ ditambahkan. Ketiga bahan tersebut dicampur sembari dipanaskan hingga diperoleh padatan polimer fenol formaldehid. Resin yang terbentuk diberi nama PF. Produk hasil polimerisasi kemudian dikeringkan dan dipecah menjadi ukuran yang seragam. Produk yang telah kering siap digunakan untuk dipirolisis atau biasa disebut dengan prekursor karbon berpori.

\subsubsection{Pembuatan Katalis $\mathrm{MgO} / \mathrm{C}$ dengan Pirolisis Polimer}

Proses pirolisis diawali dengan pemanasan polimer dari suhu ruangan sampai $850^{\circ} \mathrm{C}$ dengan kecepatan pemanasan sebesar $3,5^{\circ} \mathrm{C} /$ menit. Gas inert berupa $\mathrm{N}_{2}$ dialirkan dengan kecepatan konstan. Pengaliran gas $\mathrm{N}_{2}$ bertujuan untuk mengusir kehadiran oksigen dalam furnace serta sebagai gas pembawa zat-zat yang keluar dari bahan yang dipirolisis. Pada saat suhu telah mencapai $850^{\circ} \mathrm{C}$, steam mulai dialirkan ke dalam furnace dan proses ditahan selama 2 jam kemudian setelah itu, aliran steam dihentikan dan furnace didinginkan hingga suhu ruangan. Burn-off atau banyaknya bahan yang hilang dari proses pirolisis dihitung dengan menggunakan Persamaan (1).

$$
\text { Burn off }=\frac{w_{0}-w_{t}}{w_{0}} \times 100 \%
$$

di mana $W_{0}$ adalah massa awal prekursor dan $W_{t}$ adalah massa karbon berpori yang dihasilkan dari karbonisasi. Produk hasil pirolisis resin MPF diberi nama MgO/C. Sedangkan material pembanding berupa hasil pirolisis resin PF diberi nama C-PF.

\subsubsection{Karakterisasi Material}

Karakterisasi material karbon berpori yaitu uji serapan nitrogen dengan Quantachrome NOVA 2000 untuk mengetahui properti pori (NOVA 2000), foto morfologi permukaan dengan JSM-6360LA (JEOL) scanning electron microscope (SEM) pada voltase $15 \mathrm{kV}$, dan uji kristalinitas bahan dengan $X$-ray Diffraction (XRD). Pola XRD diambil dari posisi $2 \theta$ antara $35-80^{\circ}$.

\subsubsection{Reaksi Transesterifikasi Minyak Kelapa Sawit dan Metanol \\ Reaksi transesterifikasi antara minyak} kelapa sawit dilakukan pada reaktor batch berupa labu leher tiga $500 \mathrm{~mL}$ dengan pemanas mantel. Sistem dilengkapi dengan kondenser refluks, termometer, pengaduk merkuri, dan pengambil sampel. Labu leher tiga diisi minyak kelapa sawit sebanyak $150 \mathrm{~g}$ dan dipanaskan pada suhu reaksi $\left(65^{\circ} \mathrm{C}\right)$. Katalis $\mathrm{MgO} / \mathrm{C}$ didispersikan ke dalam 
metanol kemudian dipanaskan hingga suhu $65^{\circ} \mathrm{C}$. Metanol dan katalis kemudian dimasukkan ke reaktor. Rasio metanol:minyak yang digunakan adalah 6:1. Sampel diambil menggunakan pengambil cuplikan setiap 30 menit dan ditampung pada botol vial lalu didinginkan menggunakan air es untuk menghentikan proses reaksi. Reaksi dijalankan selama 150 menit. Jumlah minyak sawit yang bereaksi dihitung dengan menguji kadar gliserol bebas dan gliserol total untuk setiap waktu reaksi tertentu dengan volumetri. Detail prosedur diberikan dalam literatur (Bhaskara, 2021).

Kinetika reaksi antara minyak sawit dan metanol dimodelkan dengan reaksi bolakbalik seperti ditunjukkan pada Persamaan (2).

$$
A+3 B \rightleftarrows 3 C+D
$$

dengan $\mathrm{A}=$ trigliserida, $\mathrm{B}=$ metanol, $\mathrm{C}=$ gliserol, dan $D=$ metil ester. Konsentrasi komponen $A, B, C$, dan $D$ dapat ditentukan dengan Persamaan (3) - (6) dengan asumsi reaksi merupakan reaksi elementer. Selain itu, konsentrasi metil ester pada saat awal dianggap 0 dan trigliserida merupakan reaktan pembatas. Dalam penelitian ini, komponen gliserol (C) merupakan komponen yang dianalisis sedangkan komponen lain dihitung dengan menggunakan persamaan neraca massa.

$$
\begin{aligned}
& -\frac{d C_{A}}{d t}=k\left(C_{A} C_{B}-\frac{C_{C} C_{D}}{K}\right) \\
& -\frac{d C_{B}}{d t}=3 * k\left(C_{A} C_{B}-\frac{C_{C} C_{D}}{K}\right) \\
& \frac{d C_{C}}{d t}=3 * k\left(C_{A} C_{B}-\frac{C_{C} C_{D}}{K}\right) \\
& \frac{d C_{D}}{d t}=k\left(C_{A} C_{B}-\frac{C_{C} C_{D}}{K}\right)
\end{aligned}
$$

Parameter konstanta kecepatan reaksi (k) dan kesetimbangan (K) dihitung dengan meminimasi data dengan hasil pemodelan dengan fungsi objektif sesuai Persamaan (7) dengan menggunakan fungsi fminsearch di Matlab. Hubungan k sebagai fungsi suhu didekati dengan persamaan Arrhenius (Persamaan (8).

$$
\begin{aligned}
& S S E=\sum\left(C_{\text {data }}-C_{\text {persamaan }}\right)^{2} \\
& k=A * \exp \left(\frac{-E}{R T}\right)
\end{aligned}
$$

\section{Hasil dan Pembahasan}

\subsection{Polimerisasi Magnesium Salisilat-Fenol- Formaldehid}

Pada penelitian ini, magnesium salisilat dan formaldehid direaksikan terlebih dahulu dengan penambahan asam sulfat sebagai katalis. Hal ini agar resin magnesium salisilat dapat mendominasi dan kemudian fenol yang ditambahkan kemudian dapat menjadi bahan pembentuk polimer jaring/network (Prasetyo et al., 2013). Hal ini juga penting agar magnesium salisilat dapat bereaksi secara optimal. Polimer yang dihasilkan dari reaksi polimerisasi akan lebih homogen apabila fenol yang telah dilarutkan dalam formaldehid ditambahkan setelah campuran magnesium salisilat-formaldehid mulai mengental dan berwarna coklat. Dengan penambahan fenol, padatan akan mengeras dan berubah warna menjadi putih.

Representasi struktur dari polimer magnesium salisilat-fenol-formaldehid ditunjukkan pada Gambar 1. Terlihat bahwa Mg sebagai sumber katalis aktif MgO dibawa oleh magnesium salisilat dan jumlah $\mathrm{MgO}$ dapat diatur dengan memvariasikan jumlah 
magnesium salisilat yang bereaksi. Akan tetapi, jika jumlah magnesium salisilat terlalu banyak polimer yang dihasilkan akan memiliki sifat lebih rapuh. Oleh karena itu, dalam penelitian ini digunakan rasio $\mathrm{mol} / \mathrm{mol}$ magnesium salisilat: fenol: formaldehid sebesar 0,33:0,67:2,80 (resin MPF). Sebagai pembanding digunakan pula polimer resin fenolik tanpa magnesium salisilat (resin PF).

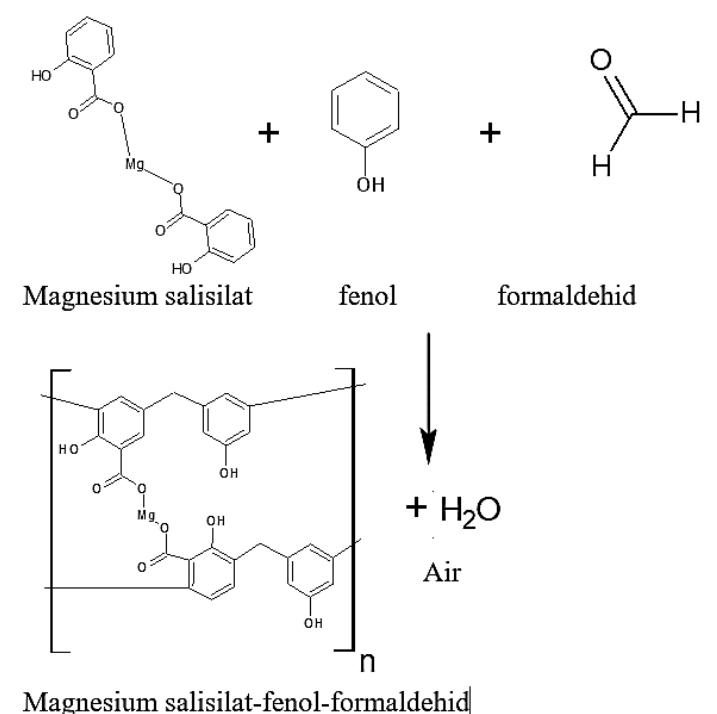

Gambar 1. Representasi struktur polimer yang diperoleh dari reaksi magnesium salisilatfenol-formaldehid

\subsection{Yield Pirolisis Polimer}

Tabel 1 menunjukkan nilai burn-off dari proses pirolisis polimer MPF dan bahan pembanding tanpa magnesium salisilat (polimer PF). Polimer MPF memiliki burn-off yang lebih rendah dibandingkan Polimer PF, masing-masing bernilai sekitar 76 dan 83\%. Hal ini dikarenakan oleh (i) struktur polimer MPF (Gambar 1) memiliki elemental O dan $\mathrm{H}$ yang lebih banyak yang berasal dari gugus $\mathrm{COOH}$ dan (ii) elemental $\mathrm{Mg}$ yang tetap dan tersisa sebagai residu pirolisis. Kedua polimer memiliki rentang burn-off antara 66-88\% seperti halnya hasil yang diperoleh oleh peneliti sebelumnya berupa pirolisis phenolic beads untuk prekursor activated carbon spheres (Singh et al., 2019). Pelepasan unsur selain karbon seperti $\mathrm{H}$ dan $\mathrm{O}$ dengan degradasi termal dapat diikuti dengan pembentukan struktur pori (Ariyanto, 2010).

Tabel 1. Burn-off proses pirolisis polimer pada suhu $850^{\circ} \mathrm{C}$ dan aktivasi menggunakan steam

\begin{tabular}{|c|c|c|c|c|}
\hline \multirow{2}{*}{$\begin{array}{c}\text { Nama } \\
\text { polimer }\end{array}$} & \multicolumn{3}{|c|}{ Perbandingan mol } & \multirow{2}{*}{ Burn-off } \\
\hline & $M$ & $\mathrm{P}$ & $\mathrm{F}$ & \\
\hline MPF & 0,33 & 0,67 & 2,80 & 75,94 \\
\hline $\mathrm{PF}$ & 0 & 1 & 2,80 & 83,23 \\
\hline
\end{tabular}

\subsection{Karakteristik Katalis $\mathrm{MgO} / \mathrm{C}$}

Karakteristik pori dari katalis $\mathrm{MgO} / \mathrm{C}$ dan material referensi karbon dari pirolisis resin $\mathrm{PF}$ (C-PF) ditunjukkan pada Tabel 2. Karakteristik pori yang ditampilkan meliputi luas permukaan spesifik total, luas permukaan spesifik mikropori, persentase luas permukaan mikropori, volum pori, persentase volum pori mikropori, dan diameter pori ratarata. $\mathrm{MgO} / \mathrm{C}$ yang berasal dari pirolisis polimer MPF memiliki luas permukaan yang lebih tinggi $\left(494 \mathrm{~m}^{2} / \mathrm{g}\right)$ dibanding C-PF (417 $\mathrm{m}^{2} / \mathrm{g}$ ). Prosentase mesopori baik dari luas permukaan maupun volume pori dari $\mathrm{MgO} / \mathrm{C}$ lebih baik dibanding C-PF. Hal ini disebabkan karena polimer PF lebih rigid sehingga cenderung memiliki volume total dan pori yang kecil, seperti diamati pada penelitian sebelumnya (Ariyanto et al., 2012). Volume pori yang relatif besar tentunya menguntungkan dari sisi transportasi molekul di dalam pori. Diameter rerata pori untuk $\mathrm{MgO} / \mathrm{C}$ dan C-PF berturut-turut bernilai sebesar 1,73 dan $1,63 \mathrm{~nm}$. Sesuai literature, jenis pori karbon pada umumnya merupakan pori slit sehingga molekul ramping masih dapat masuk ke dalam pori (Ustinov and Do, 2006). 
Tabel 2. Karakteristik struktur pori dari karbon hasil pirolisis polimer MPF dan PF

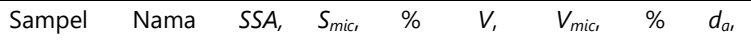
\begin{tabular}{ccccccccc} 
polimer & material & $\mathrm{m}^{2} / \mathrm{g}$ & $\mathrm{m}^{2} / \mathrm{g}$ & $\mathrm{S}_{\text {mic }}$ & $\mathrm{cm}^{3} / \mathrm{g}$ & $\mathrm{cm}^{3} / \mathrm{g}$ & $\mathrm{V}_{\text {mic }}$ & $\mathrm{nm}$ \\
\hline $\mathrm{MPF}$ & $\mathrm{MgO} / \mathrm{C}$ & 494 & 465 & 94 & 0,21 & 0,18 & 86 & 1,73
\end{tabular} $\begin{array}{ccccccccc}\text { PF } & \text { C-PF } & 417 & 407 & 97 & 0,17 & 0,15 & 91 & 1,63\end{array}$ Keterangan: $S S A=$ specific surface area; $S_{\text {mic }}=$ luas area mikropori; $V=$ volume pori; $V_{\text {mic }}=$ volume mikropori; $d_{a}$ = diameter pori rerata.

Gambar 2 menunjukkan hasil difraksi sinar$\mathrm{X}$ dari $\mathrm{MgO} / \mathrm{C}$. Peak cukup terlihat pada posisi $2 \theta$ yaitu $43^{\circ}$ dan $63^{\circ}$. Literatur menyampaikan bahwa fase kristalin nanopartikel magnesium oksida ditandai pada peak pada posisi $2 \theta$ antara $36-43^{\circ}, 61-63^{\circ}$, dan $74-78^{\circ}$ sesuai dengan standar JCPDS No.89-7746 (SafaeiGhomi et al., 2015). Peak yang didapatkan cukup rendah dan hal ini dapat disebabkan karena penyebaran $\mathrm{MgO}$ dalam karbon merata dan jumlah fraksi massa yang sedikit (Cimino et al., 2019). Berdasarkan peak $2 \theta$ dapat disimpulkan bahwa magnesium oksida terdapat pada material karbon hasil pirolisis Polimer MPF. Oleh karena itu, proses pembuatan katalis magnesium oksida dengan pengembanan secara incorporated berhasil dilakukan.

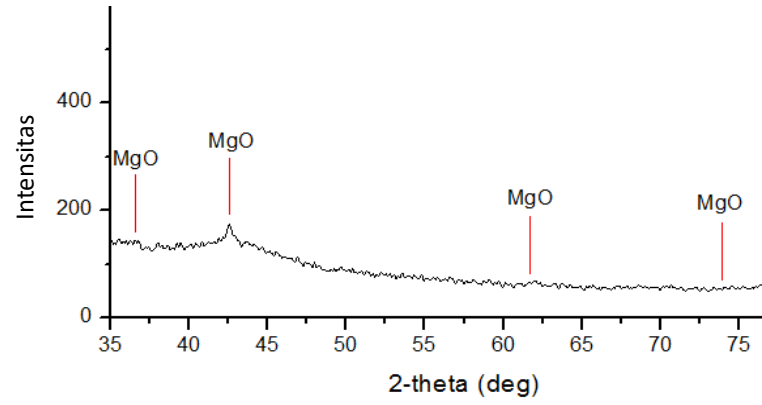

Gambar 2. Pola XRD dari material MgO/C. Peak MgO dari standar JCPDS No.89-7746

Gambar 3 menunjukkan gambar SEM dari material C-PF dan $\mathrm{MgO} / \mathrm{C}$. Material C-PF terlihat permukaannya bersih dan halus. Sedangkan $\mathrm{MgO} / \mathrm{C}$ terlihat kasar dengan material putih di permukaan karbon. Hasil ini dapat mengkonfirmasi hasil XRD bahwa $\mathrm{MgO}$ ada di permukaan material $\mathrm{MgO} / \mathrm{C}$ dan pengembanan $\mathrm{MgO}$ dalam karbon berhasil dilakukan.

\section{a}

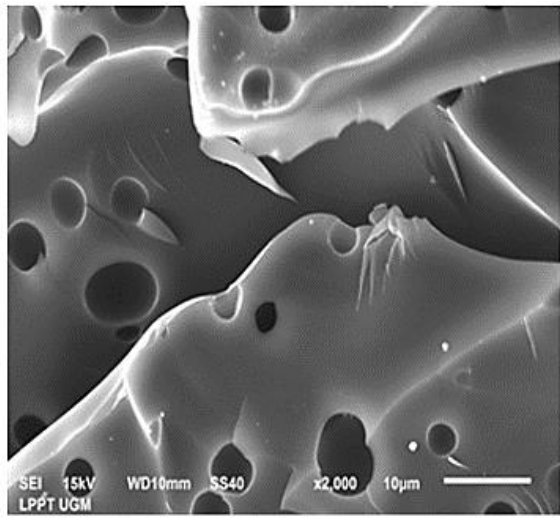

b

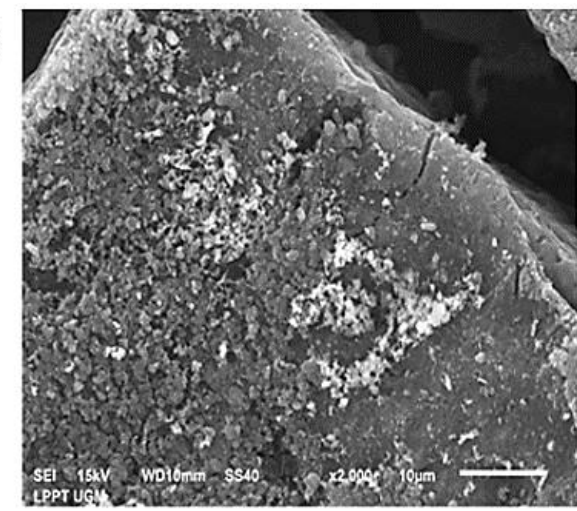

Gambar 4. Morfologi permukaan dari material C-PF (a) dan $\mathrm{MgO} / \mathrm{C} \quad(\mathrm{b})$, diambil dengan menggunakan scanning electron microscope

\subsection{Reaksi Transesterifikasi Minyak Kelapa Sawit dan Metanol dengan Katalis $\mathrm{MgO} / \mathrm{C}$}

Reaksi transesterifikasi antara minyak kelapa sawit dan metanol dilakukan pada suhu 55, 60, dan $65^{\circ} \mathrm{C}$. Konversi minyak kelapa sawit vs suhu ditunjukkan pada Gambar 5. Makin tinggi suhu maka konversi reaksi semakin meningkat dan konversi tertinggi pada penelitian sekitar 28\% diperoleh pada kondisi $65^{\circ} \mathrm{C}$ dan 150 menit. Peningkatan suhu menyebabkan molekul memperoleh energi tambahan yang diubah 
menjadi energi kinetik dalam geraknya. Akibatnya, tumbukan antar molekul pereaksi menjadi lebih besar dan produk yang dihasilkan semakin tinggi. Oleh karena itu, suhu reaksi yang tinggi akan mempercepat reaksi transesterifikasi ke arah produk, sehingga konversi minyak akan semakin tinggi. Konversi tertinggi yang didapatkan (28\%) setara dengan konversi yang didapatkan literatur lain dengan menggunakan katalis K/AC (27\%) (Pradana et al., 2018). Namun hasil yang didapatkan masih jauh dari penelitian lainnya yang menghasilkan 80-99\% konversi tetapi dengan waktu reaksi yang jauh lebih lama hingga 24 jam (Thangaraj et al., 2019).

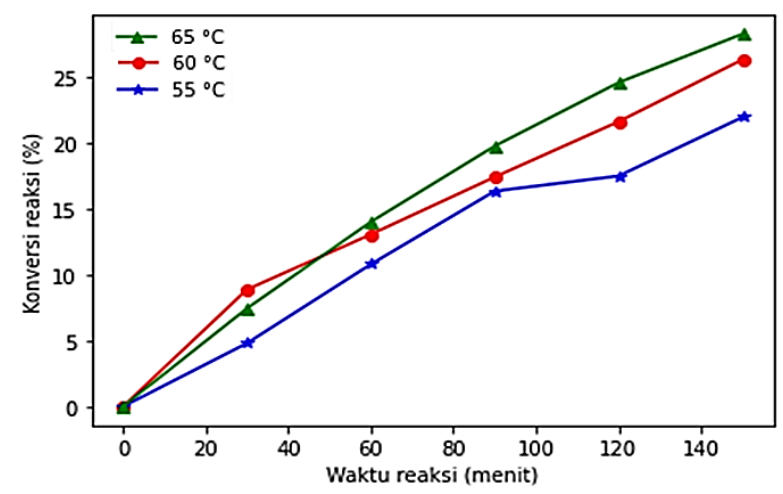

Gambar 5. Konversi reaksi transesterifikasi antara minyak sawit dan methanol pada berbagai waktu

Tabel 3. Nilai konstanta laju reaksi dan kesetimbangan pada berbagai suhu

\begin{tabular}{ccc}
\hline \multirow{2}{*}{$\mathrm{T}\left({ }^{\circ} \mathrm{C}\right)$} & \multicolumn{2}{c}{ Konstanta } \\
\cline { 2 - 3 } & $k\left(\mathrm{~L}^{2} / \mathrm{mol} / \mathrm{g} /\right.$ menit $)$ & $K$ \\
\hline 55 & $4,15.10^{-4}$ & 0,272 \\
60 & $5,15.10^{-4}$ & 0,394 \\
65 & $5,55.10^{-4}$ & 0,712 \\
\hline
\end{tabular}

Tabel 3 menunjukkan hasil nilai konstanta kecepatan reaksi dan kesetimbangan dari hasil fitting data penelitian. Nilai $k$ naik dengan naiknya suhu dan nilai berkisar antara
4-6.10-4 $\mathrm{L}^{2} / \mathrm{mol} / \mathrm{g} / \mathrm{menit}$. Sedangkan nilai $K$ didapatkan antara 0.2-0.72.

Hasil fitting nilai konstanta laju reaksi dengan Persamaan (8) menghasilkan hubungan $k=f(T)$ seperti ditunjukkan pada Persamaan (9).

$$
k=8,31 * \exp \left(\frac{-3243}{T}\right)
$$

Nilai faktor tumbukan sebesar 8,31 $\mathrm{L}^{2} / \mathrm{mol} / \mathrm{gcat} / \mathrm{menit}$ ) dan energi aktivasi sebesar $6.444 \mathrm{kal} / \mathrm{mol}$ diperoleh. Sebagai pembanding, nilai energi aktivasi sebesar $16.113 \mathrm{kal} / \mathrm{mol}$ diperoleh untuk reaksi transesterifikasi senyawa yang sama dengan katalis K/AC pada kondisi rasio reaktan 6:1 dan suhu $60^{\circ} \mathrm{C}$ (Pradana et al., 2018). Selain itu, pada penelitian transesterifikasi dengan katalis $\mathrm{CaO} / \mathrm{Y}-\mathrm{Al}_{2} \mathrm{O}_{3}$, diperoleh nilai energi aktivasi sebesar $8.403 \mathrm{kal} / \mathrm{mol}$, pada kondisi operasi suhu $75^{\circ} \mathrm{C}$ dan waktu reaksi 7 jam (Savitri et al., 2012).

\section{Kesimpulan}

Katalis $\mathrm{MgO} / \mathrm{C}$ telah berhasil dibuat dengan cara pirolisis resin fenolik berbahan dasar magnesium salisilat. Katalis $\mathrm{MgO} / \mathrm{C}$ memiliki luas permukaan spesifik sekitar 494 $\mathrm{m}^{2} / \mathrm{g}$. Keberadaan MgO dikonfirmasi dari pola difraksi XRD yang menunjukkan peak karakteristik untuk kristal $\mathrm{MgO}$ pada posisi $2 \theta$ antara $36-43^{\circ}, 61-63^{\circ}$, dan $74-78^{\circ}$ sesuai dengan standar JCPDS No.89-7746. Selain itu, gambar SEM menguatkan keberadaan kristal $\mathrm{MgO}$ di permukaan karbon. Katalis yang diperoleh dapat digunakan untuk reaksi transesterifikasi antara minyak kelapa sawit dengan methanol dengan konversi reaksi tertinggi pada penelitian ini sebesar $28,3 \%$. Selain itu, hasil evaluasi menunjukkan nilai energi aktivasi sebesar $6.444 \mathrm{kal} / \mathrm{mol}$ diperoleh untuk reaksi pada rentang suhu 55- 
$65{ }^{\circ} \mathrm{C}$. Hasil penelitian ini dapat menjadi panduan dalam penyiapan katalis berbasis $\mathrm{MgO}$ dengan cara in situ/incorporated pada prekursor karbon.

\section{Ucapan Terima Kasih}

Penulis mengucapkan terima kasih kepada Departemen Teknik Kimia FT UGM melalui Program Hibah Penelitian Departemen tahun 2020.

\section{Daftar Pustaka}

Ariyanto, T., 2010, Pembuatan Material Karbon Berpori dari Pirolisis Phenolic Resin sebagai Material Elektroda Superkapasitor, Tesis, Univ. Gadjah Mada, Yogyakarta.

Ariyanto, T., Prasetyo, I. and Rochmadi., 2012, Pengaruh struktur pori terhadap kapasitansi elektroda superkapasitor yang dibuat dari karbon nanopori, Reaktor, 14 (1), 25-32.

Bhaskara, P.T., 2021, Pembuatan Biodiesel Dari Minyak Kelapa Sawit Menggunakan Katalis MgO Terembankan Dalam Karbon Berbasis Polimer Magnesium SalisilatFenol-Formaldehid, Universitas Gadjah Mada, Yogyakarta.

Cimino, S., Apuzzo, J. and Lisi, L., 2019, MgO dispersed on activated carbon as water tolerant catalyst for the conversion of ethanol into butanol, Appl. Sci., 9, No. 1371, available at:https://doi.org/10.3390/ app9071371.

Ding, Y., Zhang, G., Wu, H., Hai, B. and Wang, L., 2001, Nanoscale magnesium hydroxide and magnesium oxide powders: Control over size, shape, and structure via hydrothermal synthesis, Chem. Mater., 13 (17), 435-440.
Glasel, J., Diao, J.Y., Feng, Z.B., Hilgart, M., Wolker, T., Su, D.S. and Etzold, B.J.M., 2015, Mesoporous and graphitic carbide-derived carbons as selective and stable catalysts for the dehydrogenation reaction, Chem. Mater., 27 (16), 5719-5725.

Haidari, S., Kamarehie, B., Jafari, A., Birjandi, M. and Afrasyabi, S., 2016, Oxalic acid degradation from aqueous solution using ozonation process in the presence of magnesium oxide nanoparticles catalyst stabilized on activated carbon, Int. J. Environ. Health Eng., 5 (3), available at:https://doi.org/10.4103/22779183.196665.

Haus, A., Reitz, G., Boehmke, G. and Meister, M., 1981, Phenolic Formaldehyde-Salicylic Acid Condensation Products, United States Patent 4245083.

Natewong, P., Murakami, Y., Tani, H. and Asami, K., 2016, Effect of support material on $\mathrm{MgO}$-based catalyst for production of new hydrocarbon bio-diesel, Am. Sci. J. Eng. Technol. Sci., 22 (1), 153-165.

Nur'aeni, D.A.K., 2019, Preparasi Dan Karakterisasi Katalis Komposit MgO-C Dari Pirolisis Polimer Magnesium SalicylatePhenol-Formaldehyde: Pengaruh Rasio Reaktan, Universitas Gadjah Mada, Yogyakarta.

Pradana, Y.S., Hidayat, A., Prasetya, A. and Budiman, A., 2018, Application of coconutshell activated carbon as heterogeneous solid catalyst for biodiesel synthesis, Defect Diffus. Forum, 382, 280-285.

Prasetyo, I., Mukti, N.I.F., Fahrurrozi, M. and Ariyanto, T., 2018, Removing ethylene by adsorption using cobalt oxide-loaded nanoporous carbon, ASEAN J. Chem. Eng., 18 (1), 9-16. 
Prasetyo, I., Rochmadi, Ariyanto, T. and Yunanto, R., 2013, Simple method to produce nanoporous carbon for various applications by pyrolysis of specially synthesized phenolic resin, Indones. J. Chem., 13 (2), 95-100.

Safaei-Ghomi, J., Zahedi, S., Javid, M. and Ghasemzadeh, M., 2015, MgO Nanoparticles: an Efficient, Green and Reusable Catalyst for the One- pot Syntheses of 2,6-Dicyanoanilines and 1,3Diarylpropyl Malononitriles under Different Conditions, J. Nanostructures, 5 (2), 153-160.

Savitri, S.D., Asri, N.P., Roesyadi, A., Budikarjono, K. and Suprapto., 2012, Kinetika Reaksi Transesetrifikasi Minyak Sawit dengan Katalis Single Promotor, Semin. Nas. Tek. Kim. Soebardjo Brotohardjono UPN "Veteran" Jawa Timur, Surabaya.

Singh, A., Aggrawal, S. and Lal, D., 2019, Effect of formaldehyde to phenol ratio in phenolic beads on pore structure, adsorption and mechanical properties of activated carbon spheres, Def. Sci. J., 69 (1), 46-52.
Siriwardane, I.W., Udangawa, R., de Silva, R.M., Kumarasinghe, A.R., Acres, R.G., Hettiarachchi, A., Amaratunga, G.A.J., et al., 2017, Synthesis and characterization of nano magnesium oxide impregnated granular activated carbon composite for $\mathrm{H}_{2} \mathrm{~S}$ removal applications, Mater. Des., 136, 127-136.

Thangaraj, B., Solomon, P.R., Muniyandi, B., Ranganathan, S. and Lin, L., 2019, Catalysis in biodiesel production - A review, Clean Energy, 3 (1), 2-23.

Ustinov, E.A. and Do, D.D., 2006, Adsorption in Slit Pores and Pore-size Distribution: A Molecular Layer Structure Theory, Adsorption, 24 (1), 1-16. 